УДК 811.161.2:003.349

https://doi.org/10.31548/philolog2020.04.111

\title{
TRANSITION FROM CYRILLIC TO ROMAN ALPHABET IN UKRAINIAN LANGUAGE
}

\author{
O. S. POLISHCHUK, PhD in Philology, Associate Professor, \\ National University of Life and Environmental Sciences of Ukraine \\ E-mail: oleksandr_polishchuk@ukr.net \\ http://orcid.org/0000-0001-9306-617X
}

\begin{abstract}
Recently, the ideas of the transition of the Ukrainian language from the Cyrillic to the Latin alphabet have become more and more popular in Ukrainian society. Thus, the former Minister for Foreign Affairs of Ukraine Pavlo Klimkin offered to discuss the possible usage of Latin alphabet alongside the Cyrillic alphabet. The purpose of research is to analyze the possibility of transition of Ukrainian language from Cyrillic to Roman alphabet. Results of research. Transliterations of the language used by the inhabitants of the middle Dnieper were first mentioned four centuries ago. In the first half of the last century, Turkey switched to Latin. After the collapse of the Soviet Union, the transition from Cyrillic to Latin was carried out in Moldova, Azerbaijan, Uzbekistan and Turkmenistan. Kazakhstan plans to switch to Latin for the Kazakh language by 2025. The reason for such a transition seems to be the noblest: to bring the Ukrainian language out of the Russian cultural space. However, there is an opinion that now is not the best time for it. Only recently - in the last 10 years - the rapid growth of book publishing in the Ukrainian language has begun. But this trend is still quite fragile, and it is easy to break. The transition to a new written language will cause a blow to publishers, from which they may not recover - many old books will remain unsold, and the promotion of new ones will take time - until people get used to the new letter, decades may pass.
\end{abstract}

Key words: Cyrillic alphabet, Latin alphabet, cultural space, reform, spelling.

Introduction. On March 26, 2019, the former Minister for Foreign Affairs of Ukraine Pavlo Klimkin in his Facebook post offered to discuss the possible introduction of Latin in Ukraine alongside the Cyrillic alphabet. He said that the idea arose during a meeting with representatives of Central European countries on the problems of the region, as well as the role of Ukraine in the Central European community. During the conversation, Polish historian and journalist Zemowit Szczerek asked why Ukraine should not introduce Latin along with Cyrillic.

Similar ideas came to Minister Klimkin. Transliterations of the language used by the inhabitants of the middle Dnieper region were first mentioned four centuries ago:

- XVII century - the birth of the idea of transliteration of the Ukrainian language into Latin. This was due to the policy of Polonization, which was carried out in the Ukrainian lands that were part of the Commonwealth.

- 1834 - Ukrainian linguist Joseph Lozynsky proposed the "alphabet" - Latin letters of the Ukrainian language based on the Polish alphabet.

- 1859 - Czech Slavic scholar losia Irecek came up with the idea of translating the Ukrainian alphabet into Latin.
- 1920-1930 - a campaign to Latinize the languages of the peoples of the USSR, including the Ukrainian language. Proponents of Latinization were Vladimir Ulyanov (Lenin) and Anatoly Lunacharsky.

- 2014 - Lviv began to promote the reform of the transition to the Latin alphabet. According to the initiators of such a reform, Latinization would bring Ukraine closer to Europe.

- 2017 - journalist Stanislav Rechinsky returned the topic of Latinization to the field of wide discussion under the slogan "The more we differ from Russia - the better" [2, 3, 4, 6, 7].

The purpose of this study is to analyze the possibility of transition of Ukrainian language from Cyrillic to Roman alphabet. Is it timely or not to introduce the Ukrainian Latin alphabet? Anyone who learns English pays attention to complex spelling rules from the very first days of studying. Moreover, for each rule there is an exception, and for an exception - one more exception.

In this regard, French is also similar to English, however, there are much fewer exceptions, and the spelling is much more predictable, but is it simple? Hardly. How, interestingly, a person who does not know French reads the name Lemieux (ukr. Лем'є)?

Anyone who has studied English, French, German, Italian, etc. sooner or later put himself 
a question: maybe it would be better to simplify orthography in order to make spelling is more logical and predictable?

People who thought about reforms in English, French, German spelling, least of all thought about how to make it easier for people who live somewhere far away to learn the language. It was primarily about how the costs of the new spelling of words would not turn out to be more expensive for their own benefits. In all cases, the costs were prohibitively expensive.

The strongest side of the English language is also problem number one: it is an international language. It has long gone beyond the UK and is the main language for several dozen countries around the world. That is, if one country raises the spelling reform initiative, it is not a fact that the rest will support it.

Neither the UK nor the United States regulates language issues at all at the government level. The government can decide which programs to support in schools, but it's not its business to standardize spelling. In Britain, English is rationed by two centers, Oxford and Cambridge. In the United States, there are large universities that publish dictionaries and maintain corpus (databases) of the language - but they have no right to dictate their own rules.

English is not the official language in the United States at all - this status is not assigned to it in the Constitution or federal law. That, of course, does not cancel its position as the main language de facto. Even in those states where some of the counties are mostly Hispanic, attempts to introduce bilingual education in schools were rejected by the public.

That does not mean, however, that the English language is forever frozen in an unchanged state and there is no one to change it. In democratic countries, there is the concept of "public initiative", which can be strong enough to, among other things, make changes in the language.

At the dawn of the emergence of the United States, a group of reformers, among whom was Benjamin Franklin, proposed to simplify the spelling of a number of widely used words: theater instead of theater, plow instead of plow, etc. These changes, along with some of the smaller and more recent ones, created a distinction between American and British spellings.

Moreover, most English-speaking countries (including large ones such as Canada) use a "hybrid" spelling, mixing British and American norms.
If the first problem of the English language is its "internationality", and the second in its "non-government", then the third is that Englishspeaking countries are countries with welldeveloped private business. And where there is a private business, there are trademarks.

Lawsuits can be not only about lost funds for brand promotion. There will be many cases where previously different brands will suddenly become the same - precisely because of the simplified spelling. This is not uncommon in the English-speaking world. There are, say, the names Cathryn, Catherine, Kathryn - it is clear that all three are different girls. And if they simplify spelling, how can they be distinguished from each other?

English is an international language not only because it has an official status in many states. It is the language of international business, international politics and science. The English language has fought for this status for a long time and does not intend to just give in and lose it. Spelling reform can easily knock the ground out of its international status. After all, English, thanks to its many international contacts, thanks to immigrants, contains a considerable layer of international vocabulary. Words like economy, international, example, etc. are easily recognizable, at least in appearance, by Europeans, Latinos, and even residents of the former USSR. But will it be easy to recognize, for example, the words imoushn, revolushn instead of the usual emotion, revolution? Hardly.

In states with a "authoritarian state, no one asks questions. They got an ordered - and the reform starts. However, it only seems that dictators are omnipotent. Mao Zedong began to reform the Chinese hieroglyps in order to simplify their writing, so that there were fewer lines. And most importantly, the Japanese invaders had already done a significant part of the work (they began to simplify the hieroglyphs, but did not have time to go as far as the Chinese). When the first stage of the reform passed, the Chinese communists wanted to simplify the hieroglyphs even more. But then the people began to be indignant everywhere: how are we going to read the old documents? And why did we spend 10 years learning new hieroglyphs - to relearn again? In general, the reform stopped halfway.

In Germany, for a long time, the Gothic font was considered a symbol of national identity and stubbornly refused to change it to the usual Latin alphabet (despite the fact that Germanspeaking ones in neighboring Austria and 
Switzerland switched to it). Bismarck demonstratively disdained to accept books printed in German in Latin as a gift. The Nazis, having come to power, began with might and main to restore "identity", to which the Gothic script was also ranked. But as soon as the Nazis seized several countries, it was immediately discovered that no one had stocked up with the Gothic font specially for the arrival of the occupiers. They had to print documents and newspapers in the usual Latin alphabet, and in 1941 the Gothic font was abolished in Germany itself. Expediency turned out to be much more important than voluntarism and invented "identity".

If you look at the history of spelling reforms [4, $7,8]$, especially in the last $100-200$ years, it turns out that they were easiest and fastest in those cases when at once a lot of the old turned out to be unnecessary and irrelevant - so that its loss did not look too great. For example, in 1925, Mustafa Kemal introduced the Latin alphabet in Turkey (and soon the Latin alphabet was introduced for the Turkic-speaking peoples of the USSR). If such a reform had been started in the Ottoman Empire at the end of the 19th century, the author would have been stoned as an atheist and apostate. But Kemal was not the president of the Ottoman Empire, which included most of the Arabic-speaking lands, but Turkey itself, where there were almost no Arabs left. The former literary language of the Ottoman Empire, which included many Arabic and Persian words, was incomprehensible to most ordinary Turks, and only a few knew it. Therefore, Kemal's reform was a success [11].

But in the USSR it turned out worse. The transition to the Latin alphabet took place in approximately the same conditions as Kemal's only a few people knew the Arabic alphabet. New local literature began to develop quickly. But Stalin quickly realized that the Turkicspeaking peoples have an alternative cultural reality - with the center in Istanbul, and not in Moscow. In the 1930s, by a strong-willed order,

\section{Refrences}

1. Vakulenko, M. (2010). Suchasni aspekty zastosuvannya ukrains'koy latynytsi [Modern Aspects of Using Latin Alphabet in Ukrainian Language]. Naukovi zapysky. Seriya: Filolohichni nauky (movoznavstvo). Kirovohrad: KDPU im. V. Vinnichenka, 89 (2), 140-145. [in Ukrainian].

2. Ivchenko, M. P. (1965). Suchasna ukrayins'ka literaturna mova [Modern Ukrainian Literary Language]. Kyiv. [in Ukrainian]. the Turkic peoples were already transferred to the Cyrillic alphabet, which dealt a blow to their education and culture, the consequences of which were disastrous. Not so long ago in Russia, the Tatars were forbidden to have the Latin alphabet - they say, the Cyrillic alphabet better conveys sounds of Tatar language. The real reason was the same - to prevent the creation of an alternative cultural reality in which the Tatar language would no longer be so dependent on Russian [5, 8, 11].

At first sight, the reason for the transition of the Ukrainian language to the Latin alphabet seems noble: to withdraw the Ukrainian language from the Kremlin's cultural space. However, now is not the best time for this.

In the last 10 years, the rapid growth of book publishing in the Ukrainian language has begun. But this trend is still quite delicate and easy to break. The transition to a new writing system will deal a blow to publishers from which they may not recover. Many old books will remain unsold, and new ones will take time to promote. It may take decades for people to get used to the new alphabet.

Azerbaijanis and Moldovans switched to the Latin alphabet because in Soviet times it was not too foreign - literature came to Moldova from Romania, Azerbaijanis understood closely related Turkish and could, even if semi-legally, read Turkish literature, now many of them watch Turkish television.

It would seem that Poland, the Czech Republic, and Slovakia are next to Ukraine. But the facts are that for the majority of Ukrainians these countries are still exotic. Perhaps, in 1020 years, many Ukrainian families will discuss the realities of Poland in the same way as now, unfortunately, they still discuss Russian TV shows and films (which they continue to watch despite the restrictions). When the Polish realities will become "our own", then it will be possible to talk about the introduction of the Ukrainian Latin alphabet. In the meantime, we will use the Cyrillic alphabet.

3. Isayevych, Ya. Pol's'komovne i latyns'ke drukarstvo [Polish and Latin prtinting]. Ukrayins'ke knyhovydannya: vytoky, rozvytok, problemy. L'viv: In-t ukrayinoznavstva im. I. Krip'yakevicha NAN Ukrayiny, 222-229. [in Ukrainian].

4. Moyyeseyenko, V. (1997). Pro odnu sprobu latynizatsiyi ukrayins'koho pys'ma [About One Attempt of Latinization of Ukrainian Written Language]. "YI»: Hezalezhnyy kul'turolohichnyy chasopys, 10. [in Ukrainian]. 
5. Reformatskyy, A. A. (1960). Transliteratsiya russkikh tekstov latinskimi bukvami [Transliteration of Russian Texts Using Latin Alphabet]. Voprosy yazykoznaniya, 5, 96-103. [in Russian].

6. Synyavs'kyy, O. (1931). Korotka istoriya «Ukrayins'koho pravopysu» [Short History of Ukrainian Spelling]. Kul'tura ukrayins'koho slova: zb. Nauk.-doslidchoho in-tu T. Shevchenka. Kharkiv; Kyiv, 93-112. [in Ukrainian].

7. Tymchenko, Ye. (2004). Desiderata v spravi nashoho pravopysu [Diserdata in the Case of Our Spelling]. Istoriya ukrayins'koho pravopysu. XVI-XX st. Kyiv : Naukova dumka, 188-192 [in Ukrainian].

8. Chornovol, I. (2001). Latynka v ukrayins'komu pravopysi: retrospektyva i perspektyva [Latin Alphabet in Ukrainian
Spelling: Retrospective and Perspective]. «YI» : Nezalezhnyy kul'turolohichnyy chasopys, 23. [in Ukrainian].

9. Comrie, B., \& Corbett, G. G. (Eds.). (2003). The Slavonic Languages. London : Routledg. [in English].

10. Grujič, Br., \& Srdevič, M. (1996). Srpskohrvatsko-ruski džepni rečnik. Beograd. [in Srpskohrvatski].

11. Kasianov, G. \& Ther, Ph. (Eds.). (2009) A Laboratory of Transnational History. Ukraine and Recent Ukrainian. Historiography (p. 208). Budapest, NewYork : Central European University Press. [in English].

12. Vakulenko, M. (2004, September). Simple-correspondent transliteration through a Slavonic Latin alphabet. Journal of Language and Linguistic Studies, 3 (2), 213-228. [in English].

\section{ПЕРЕХІД УКРАЇНСЬКОЇ МОВИ З КИРИЛИЦІ НА ЛАТИНСЬКИЙ АЛФАВІТ \\ О. С. Поліщук}

Анотація. Останнім часом в українському суспільстві все частіше звучать ідеї переходу української мови з кириличного на латинський алфавіт. Так, колишній міністр закордонний справ України Павло Клімкін у своєму пості на Facebook запропонував обговорити можливе введення в Україні латиниці поруч з кириличним алфавітом. Подібні ідеї з'являлися і до міністра Клімкіна.

Вперше про транслітерації мови, якою користувалися жителі середнього Придніпров'я, заговорили ще чотири століття тому. У першій половині минулого століття на латиницю перейшла Туреччина. Після розпаду СРСР перехід від кирилиці на латиницю було проведено в Молдавії, Азербайджані, Узбекистані і Туркменістані. Казахстан планує перехід на латиницю для казахської мови до 2025 року.

Резон такого переходу видається найблагородніший: вивести українську мову з російської культурного простору. Однак, побутує думка, що зараз для цього далеко не кращий момент.

Тільки недавно - буквально в останні 10 років - почалося швидке зростання книговидання українською мовою. Але ия тенденція поки ще досить тендітна, і зламати їі легко. Перехід на нову писемність завдасть удар по видавництвах, від якого вони можуть і не оговтатися безліч старих книг залишаться нерозпроданими, а на розкручування нових знадобиться час поки народ буде звикати до нового листа, пройти можуть десятиліття.

Ключові слова: кирилиця, латинський алфавіт, культурний простір, рефрорма, правопис. 